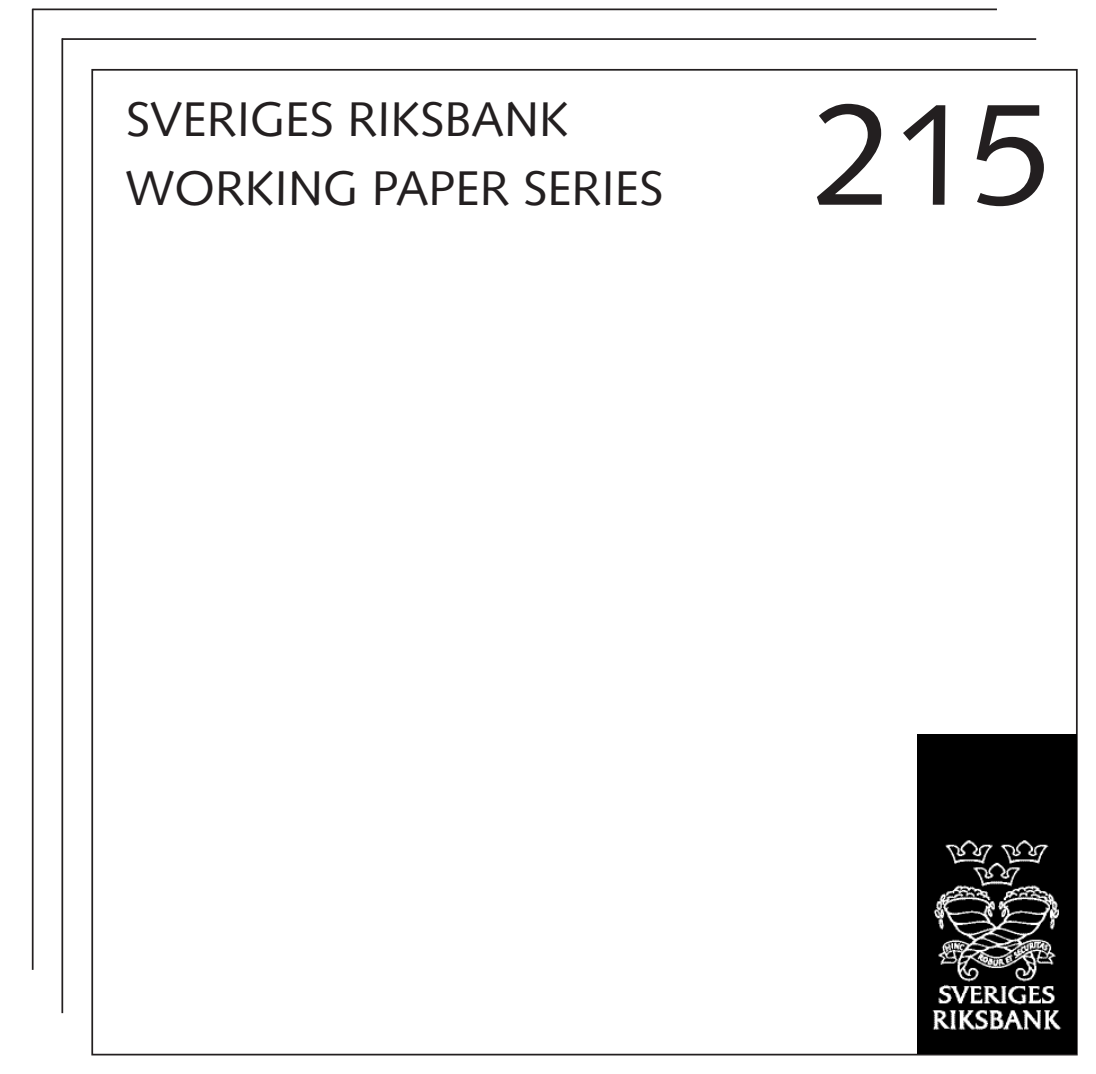

\title{
Earnings Inequality and the Equity Premium
}

Karl Walentin

NOVEMBER 2007 
WORKING PAPERS ARE OBTAINABLE FROM

Sveriges Riksbank •Information Riksbank • SE-103 37 Stockholm Fax international: +4687870526

Telephone international: +4687870100

E-mail: info@riksbank.se

The Working Paper series presents reports on matters in the sphere of activities of the Riksbank that are considered to be of interest to a wider public.

The papers are to be regarded as reports on ongoing studies and the authors will be pleased to receive comments.

The views expressed in Working Papers are solely the responsibility of the authors and should not to be interpreted as reflecting the views of the Executive Board of Sveriges Riksbank. 


\title{
Earnings Inequality and the Equity Premium*
}

\author{
Karl Walentin ${ }^{\dagger}$ \\ Sveriges Riksbank Working Paper Series
}

No. 215

November 2007

\begin{abstract}
We present data from the Survey of Consumer Finances showing that the increased earnings (labor income) inequality, in combination with increased stockmarket participation, has roughly doubled stockholders' share of aggregate labor income in the last four decades. We explore the impact of the increase in this share on returns to equity and returns to a risk-free bond in a model with limited stockmarket participation, labor income and borrowing constraints. The main result is that the increase in stockholders' share of aggregate labor income has lead to 130 basis points (45 percent) decrease in the ex ante equity premium (i.e. the discount rate applied to equity). The reason for this change is that the increase in stockholders' share of aggregate labor income leads to a change in income composition for stockholders - an increase in the fraction of their income that consists of labor income and a decrease in the fraction that consists of dividend income. This reduces the covariance between stockholder income growth and dividend growth. The size of the decrease in the equity premium implied by our model roughly coincides with the historical change in the post-1951 equity premium implied by the simple dividend growth model in Fama and French (2002).
\end{abstract}

Keywords: labor income, earnings inequality, asset pricing, equity premium, limited participation, borrowing constraints

JEL classification: D31, E24, E44, G12

${ }^{*}$ Thanks to Diego Comin, Mark Gertler, Paolo Giordani, Hui Guo, Jinyong Kim, Lars Ljungqvist, Sydney Ludvigson, Kevin Moore, Virginia Queijo von Heideken, Paolo Sodini, Ingvar Strid, Gianluca Violante and seminar participants at New York University, Stockholm School of Economics, EEA Meetings 2006 (Vienna) and Sveriges Riksbank for helpful comments. The views expressed in this paper are solely the responsibility of the author and should not be interpreted as reflecting the views of the Executive Board of Sveriges Riksbank.

${ }^{\dagger}$ Sveriges Riksbank, Research Department, 10337 Stockholm, Sweden. Phone: +46-8-787 0491. E-mail: karl.walentin@riksbank.se 


\section{Introduction}

Two important macroeconomic changes in the U.S. economy in the last decades have been the increase in earnings (labor income) inequality and the long term increase in stock prices. In this paper we set up a model to analyze the effects on equity returns of increased earnings inequality, or more specifically, an increase in stockholders' share of aggregate labor income. ${ }^{1}$

Stock prices measured as the Price/Dividend $(\mathrm{P} / \mathrm{D})$ ratio of the $\mathrm{S} \& \mathrm{P}$ index has more than tripled since 1980. The rising $\mathrm{P} / \mathrm{D}$ ratio has arguably been caused by a fall in ex ante equity return, i.e. the equity discount rate. This interpretation is forcefully laid out by Fama and French (2002). ${ }^{2} 3$ They calculate that the equity premium implied by a simple dividend growth model was 160 basis points lower in 1951-2000 (at $255 \mathrm{bp}$ ) than in 18721950 (at $417 \mathrm{bp}$ ), representing a $39 \%$ change. Furthermore, they show that the equity premium, calculated in this way, decreased monotonously decade by decade from 1950 . Fama and French conclude that the increase in stock prices in the last couple of decades must be interpreted as unexpected capital gains due to a fall in the equity discount rate. In this paper we propose an answer to why the equity discount rate has declined.

Our claim is that the decline in the equity discount rate has been caused by the increase in stockholders' share of aggregate labor income. This increase led to a change in income composition for stockholders - an increase in the fraction of their income that consists of labor income and a decrease in the fraction that consists of dividend income. This reduced the covariance between stockholder income growth and dividend growth, and thereby the $e x$ ante equity premium. Figure 1 plots the time series for the S\&P P/D ratio and stockholders' share of aggregate labor income computed using data from the Survey of Consumer Finances (SCF). Note the close relationship.

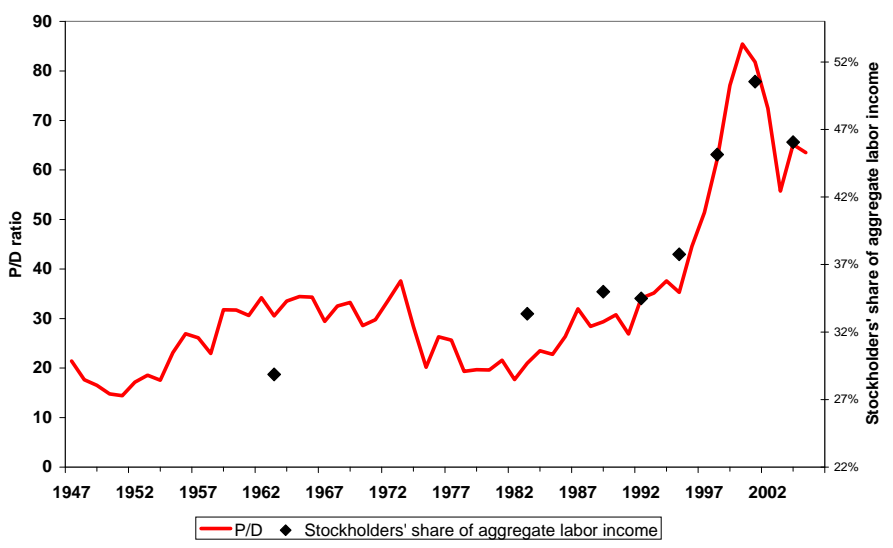

Figure 1. S\&P Price/Dividend ratio 1947-2005 and stockholders' share of aggregate labor income 1962-2003. Source: Robert Shiller's website and Survey of Consumer Finances, author's calculations.

\footnotetext{
${ }^{1}$ The increasing wage and earnings inequality is well-documented, see Piketty and Saez (2003), Katz and Autor (1999), Heathcote, Storesletten and Violante (2004), Dew-Becker and Gordon (2005) and others.

${ }^{2}$ The falling equity premium has also been documented in Blanchard (1993), Cochrane (1997), Jagannathan, McGrattan and Scherbina (2000) and Campbell (2007).

${ }^{3}$ It should be noted that stock prices measured as Price/Earnings ratios behave very similarly. Nor is the increase limited to the $\mathrm{S} \& \mathrm{P}$ index.
} 
To the best of our knowledge, this paper is the first to document the changes in stockholders' and non-stockholders' labor incomes. Some inspiration came from Mankiw and Zeldes (1991) work on the consumption of these two groups. As can be seen in Figure 1, between 1962 and 2000 stockholders' share of aggregate labor income increased from $29 \%$ to $51 \%$ (and then decreased to $46 \%$ in 2003 ).

The increase in stockholders' share of aggregate labor income can be decomposed into two parts: increased stockmarket participation and increased earnings dispersion between these two groups. Note that stockholders on average have higher labor income than nonstockholders, so that this indeed was an increase in earnings inequality. ${ }^{4}$. The two factors contributed in roughly equal amounts to the change. Because of lack of panel data, an exact decomposition of these two effects is impossible without making strong assumptions regarding the earnings of the households that switched groups (became stockholders or nonstockholders) during this period. The stockmarket participation rate is plotted together with stockholders' share of aggregate labor income in Figure 2. Table A1 presents the same information as well as average earnings for both groups.

One sign of the importance of increased earnings inequality is that stockholders' share of aggregate labor income increased 11 percent more than stockmarket participation, during the period 1962-2000. ${ }^{5}$ Furthermore, we note that the difference between these two fractions is closely related to the earnings share of the top $10 \%$ earnings individuals. This is illustrated in Figure 3.

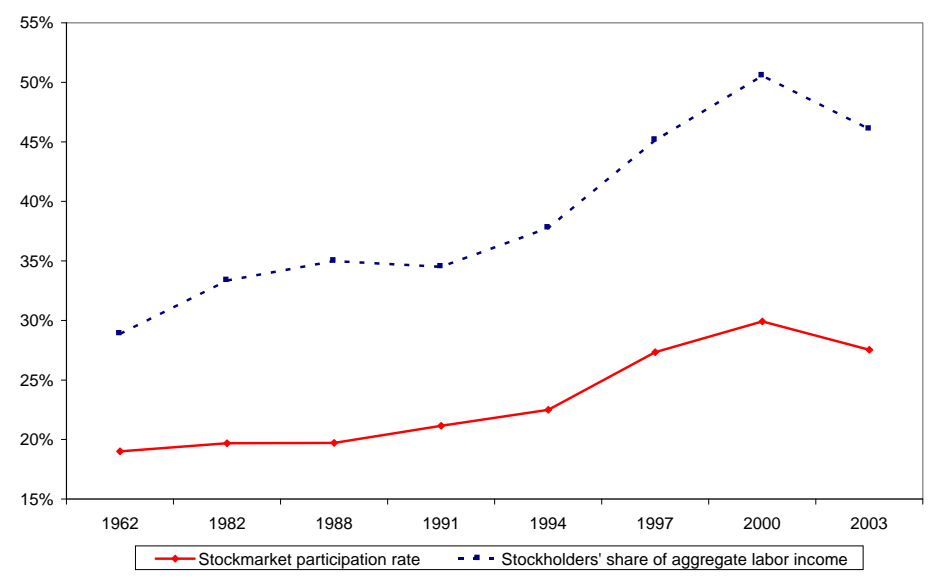

Figure 2. Stockmarket participation rate and stockholders' share of aggregate labor income. Source: Survey of Consumer Finances, author's calculations.

\footnotetext{
${ }^{4}$ Mankiw and Zeldes (1991) showed this using PSID data and the author's own analysis of SCF data confirms this result.

${ }^{5}$ Given that average earnings of non-stockholders in 1962 was roughly half that of stockholders, increased participation would plausibly pull down the average earnings of stockholders. As seen in Table A1, any such effect was quantitatively dwarfed by the increase in earnings inequality.
} 


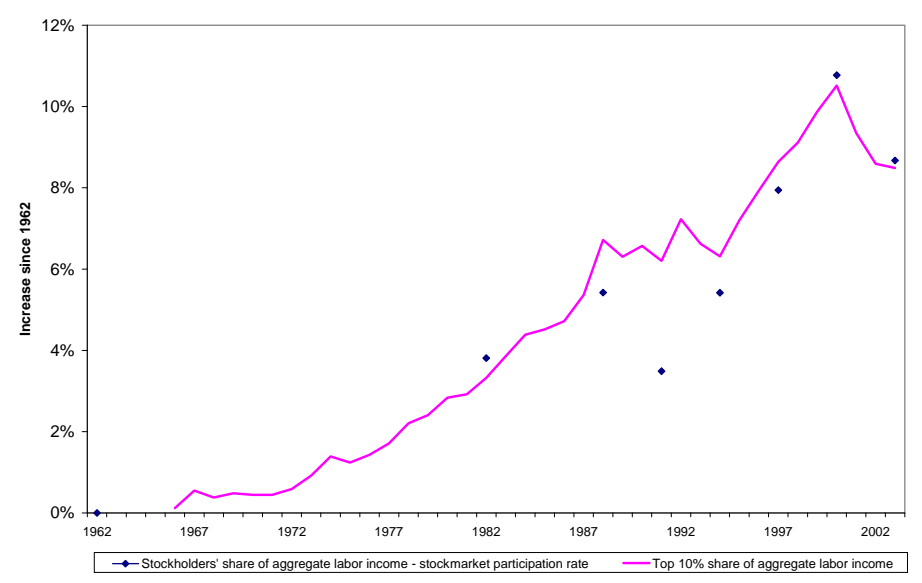

Figure 3. Stockholders' share of aggregate labor income minus the stockmarket participation rate, and earnings of top $10 \%$. Both time series are normalized to zero in 1962. Source: SCF and Piketty and Saez (2003).

We explore the impact of increased stockholder labor income on stock returns and the risk-free interest rate in a model with limited stockmarket participation and borrowing constraints. Our modeling framework is loosely based on Heaton and Lucas (1996), although they assumed full participation, and Guo (2004). We choose to use this type of model because it allows for limited participation in the stockmarket and it has already been shown to be able to match the empirical level of the equity return and the risk-free rate. Our key experiment is to calculate steady state asset returns for two different levels of stockholders' share of aggregate labor income. As mentioned above, the increase in stockholder labor income leads to a change in income composition for stockholders - a higher fraction of their income now comes from labor. This reduces the covariance between stockholder income growth and dividend growth. The equity premium accordingly falls. The quantitative impact is substantial: The historically observed increase in stockholders' share of aggregate labor income 1962-2000 generates a decrease in the equity premium by $45 \%$, from 300 basis points to 170 basis points. This change in the equity premium is very close to one calculated by Fama and French.

Two aspects of the asset pricing implications of changing labor income of stockholders have been explored in the existing literature. The first aspect is increased stockmarket participation. Several authors have explored the implications of this aspect in models that incorporate labor income. Heaton and Lucas (1999) and Polkovnichenko (2004) both show that increased participation only have limited quantitative impact on the equity premium. Basak and Cuoco (1998), on the other hand, show that participation rates can have large quantitative effects on both the stock return and the risk-free return. Guvenen (2005) shows that limited participation is very important for generating a large equity premium. The second aspect is changes in the aggregate labor share. Santos and Veronesi (2006) used the labor share of total consumption in the economy to make a similar covariance argument we use in this paper, but for short term horizons. They showed that the labor share predicts equity returns 1-4 years ahead. 
We are not aware of any other paper that explores the impact of the increased earnings inequality on equity prices. ${ }^{6}$ Gollier (2001) and Hatchondo (2005) analyze the relationship between wealth inequality and the equity premium, but in an Arrow-Debreu setting analyzing the effect of absolute risk aversion that is concave in wealth (DARA). The effect of increased wealth inequality on the equity premium is negative in the DARA setting. Our model generates this effect endogenously using borrowing constraints and limited participation, while Gollier's result follows directly from the assumption of DARA. Nakajima (2005) explores the effect of the increase in earnings volatility on house prices and debt. His main mechanism is that a more volatile earnings process leads to an increase in precautionary savings. Iacoviello (2007) studies the link between earnings inequality and household debt, including the transition dynamics.

Several potential explanations of the decrease in the equity discount rate (ex ante equity return) have been proposed. The dominant theory is that a decline in macroeconomic volatility caused the decrease in the equity discount rate (Lettau, Ludvigson and Wachter (2007)). Others have suggested that the equity premium fell because of a structural decrease in market volatility (Pástor and Stambaugh (2001) and Kim, Morley and Nelson (2004, 2005)), a reduction in transaction costs (Heaton and Lucas (1999)), increased availability of sophisticated financial instruments (Calvet, Gonzalez-Eiras and Sodini (2004)), or that the risk premium varies with the amount of risk sharing made possible through housing collateral (Lustig and Van Nieuwerburgh (2006)). As in the present paper, Freeman (2006) focuses on limited participation and high income households. Freeman's point is that the decline in volatility of the income of these households led to a fall of the equity premium. These proposed explanations are not mutually exclusive, neither with each other, nor with the explanation proposed in the present paper.

Our exercise would be less interesting if the increase in earnings inequality only applied to annual cross-sectional inequality and not to lifetime earnings. But this is not the case. Bowlus and Robin (2004) document that for the period with substantial increase in inequality, 1977-1997, the increase in inequality in lifetime earnings and annual earnings is the same. Primiceri and van Rens (2004) show that the increase in inequality in the 1980s predominately was permanent. ${ }^{7}$ The increase in earnings inequality is also robust to different measurement methods. It is evident both in tax records, as documented by Piketty and Saez (2003), and in all major household surveys (CES, CPS, PSID and SCF) ${ }^{8}$.

The paper proceeds as follows. In the next Section we describe the model. Section 3 describes the parameterization with a particular focus on the estimation of the income processes. In Section 4 we present the results and Section 5 concludes.

\footnotetext{
${ }^{6} \mathrm{~A}$ more recent paper than the present one that adresses similar questions is Favilukis (2007).

${ }^{7}$ Results in Krueger and Perri (2003) point in a different direction. Their estimates indicate that most of the "within-group" inequality increase is transitory.

${ }^{8}$ CES: Krueger and Perri (2003). CPS: Katz and Autor (1999). PSID: Heathcote, Storesletten and Violante (2004). SCF: Author's own calculations.
} 


\section{Model}

\section{$2.1 \quad$ Overview}

Our key experiment is to study the effects on equity prices of an exogenous redistribution of labor income from non-stockholders to stockholders, as observed in the last couple of decades. We analyze two different economies (i.e. steady states), one with stockholders' share of aggregate labor income set to $1962^{9}$ values and one to 2000 values. By looking at two totally separate economies instead of explicitly studying the transition from one endowment process to another we abstract from all the transition dynamics and implicitly assume that the change in labor inequality was unexpected and permanent.

To explore the effect of changing earnings inequality on stock returns and the risk-free interest rate we set up a model with limited participation ${ }^{10}$ and risk averse agents that are heterogeneous in their labor income processes. For simplicity, in each of our two economies, we let each agent's share of aggregate labor income be fixed over time. In this respect our approach differs from Heaton and Lucas (1996) and Guo (2004).

Our model and the empirical implementation focus entirely on the working-age population and abstract from the portfolio problem of retired households, and any potential life-cycle effects. We find this abstraction justifiable for the purpose of this paper, in spite of the importance of constrained young households for the equity premium indicated by Constantinides, Donaldson and Mehra (2002).

The following subsection is a stylized illustration of the main mechanism - how an increase in stockholders' share of aggregate labor income leads to a reduction of the equity premium.

\subsection{Simplified illustration model}

There are two agents - one stockholder (denoted by superscript s) and one hand-to-mouth non-stockholder (denoted by $\mathrm{n}$ ). Stockholder income consists of labor income $W^{s}$ and dividend income $D$. No trade in financial assets is allowed, and there is no steady state growth.

Preferences are described by:

$$
E \sum_{t=0}^{\infty} \beta^{t} u\left(C_{t}^{i}\right), \quad i=\{s, n\}
$$

where $\beta$ is the subjective discount factor, $C_{t}^{i}$ denotes consumption of the perishable good

\footnotetext{
${ }^{9}$ The year 1962 was chosen due to data limitations. We would prefer a slightly later year as our starting point, roughly 1970, because we know from other sources that income inequality and stockmarket participation were relatively stable until then.

${ }^{10}$ To get limited participation endogenously we could introduce fixed participation costs for the stockmarket. Given the fixed cost and the larger benefit of participation as a function of wealth, there is a cut-off in total wealth (including expected future labor income) above which participation is optimal, see Gomes and Michaelides (2006) and Polkovnichenko (2004).

Vissing-Jørgensen (2002) calculates the size of the participation cost that is needed to explain half of the empirically observed non-participation to 50 dollars annually.
} 
and

$$
u\left(C_{t}^{i}\right)=\frac{\left(C_{t}^{i}\right)^{1-\gamma}}{1-\gamma}
$$

Because of the absence of financial markets no actual consumption/saving choice is made. Instead each agent consumes his total income, $Y_{t}^{i}$, period by period. For the stockholder:

$$
C_{t}^{s}=Y_{t}^{s}=W_{t}^{s}+D_{t}
$$

The ("shadow") risk-free rate can be calculated using the Euler equation:

$$
1=R_{t}^{f} \beta E_{t}\left\{\frac{u^{\prime}\left(C_{t+1}^{s}\right)}{u^{\prime}\left(C_{t}^{s}\right)}\right\}
$$

For equity the Euler equation is:

$$
1=E_{t}\left\{R_{t+1}^{e} \beta \frac{u^{\prime}\left(C_{t+1}\right)}{u^{\prime}\left(C_{t}\right)}\right\}
$$

Assume log-normality of shocks. Take unconditional expectations, linearize by taking logs, and rearrange terms. Equation (1) can then be rewritten as:

$$
E\left(r^{e}\right)=E\left(r^{f}\right)+\gamma \operatorname{Cov}\left(r^{e}, \Delta \hat{C}\right)
$$

where we denote log returns by lower case, and other log variables by "hats". The difference in returns between the risk-free asset and equity is the equity premium, EP.

Under the assumption of joint i.i.d. process for $\Delta \hat{D}$ and $\Delta \hat{C}$, it follows that $r_{t}^{e}=\Delta \hat{D}_{t}$ (see Abel (2006)). Then equation (2) can we written as

$$
E\left(r^{e}\right)=E\left(r^{f}\right)+\gamma \operatorname{Cov}(\Delta \hat{D}, \Delta \hat{C})
$$

Labor and dividend income growth follow a joint i.i.d. process and are potentially correlated. The standard deviations are denoted by $\sigma_{\Delta \hat{W}}$ and $\sigma_{\Delta \hat{D}}$ respectively.

Stockholder income growth, and accordingly stockholder consumption growth, can be approximated as:

$$
\Delta \hat{C}_{t}^{s}=\frac{W^{s}}{W^{s}+D} \Delta \hat{W}_{t}^{s}+\frac{D}{W^{s}+D} \Delta \hat{D}_{t}
$$

where $W^{s}$ and $D$ denote the respective steady state values. We can then write the covariance as:

$$
\operatorname{Cov}\left(\Delta \hat{D}, \Delta \hat{C}^{s}\right)=\frac{W^{s}}{W^{s}+D}\left[\operatorname{corr}\left(\Delta \hat{D}, \Delta \hat{W}^{s}\right) \sigma_{\Delta \hat{D}^{\sigma_{\Delta}}}{ }_{\Delta \hat{W}^{s}}-\sigma_{\Delta \hat{D}}^{2}\right]+\sigma_{\Delta \hat{D}}^{2}
$$

where we have used $\frac{D}{W^{s}+D}=1-\frac{W^{s}}{W^{s}+D}$.

Equation (4) contains the key result: If $\operatorname{corr}\left(\Delta \hat{D}, \Delta \hat{W}^{s}\right) \sigma_{\Delta \hat{W}^{s}}<\sigma_{\Delta \hat{D}}$, or equivalently $\operatorname{Cov}\left(\Delta \hat{D}, \Delta \hat{W}^{s}\right)<\operatorname{Var}(\Delta \hat{D})$, then $\operatorname{Cov}\left(\Delta \hat{D}, \Delta \hat{C}^{s}\right)$, and thereby the equity premium, is decreasing in $\frac{W^{s}}{W^{s}+D}$, the fraction of stockholders' income that comes from labor. Note that 
$\frac{W^{s}}{W^{s}+D}$ is monotonously increasing in $W^{s}$. We conclude that if the above inequality holds, an increase in steady state stockholder labor income $W^{s}$ leads to a decrease in the equity premium.

\subsubsection{Parameterization}

Using the above results we can calculate the change in the equity premium between 1962 and 2000. Denote GDP by $Y^{a}$. We assume a capital share of $E\left(D / Y^{a}\right)$ of 0.3 . This implies a labor share of 0.7. We use the SCF to parameterize stockholders' share of aggregate labor income, $\eta^{s}: 0.289$ in 1962 and 0.505 in 2000 . We can then calculate $E_{1962}\left(\frac{W^{s}}{W^{s}+D}\right)=$ 0.402 and $E_{2000}\left(\frac{W^{s}}{W^{s}+D}\right)=0.541$. The parameter, $\operatorname{corr}\left(\Delta \hat{D}, \Delta \hat{W}^{s}\right)=-0.86$, is from our estimation of a bivariate VAR of $\left(\frac{Y_{t}^{a}}{Y_{t-1}^{a}}, \frac{D_{t}}{Y_{t}^{a}}\right)$. See Section 3 for details of the VAR estimation. ${ }^{11}$. From the VAR we also get $\sigma_{\Delta \hat{D}}=0.108$ and $\sigma_{\Delta \hat{W}}=0.042$.

Inserting the 1962 parameter values into (4) yields:

$$
\operatorname{Cov}\left(\Delta \hat{D}, \Delta \hat{C}^{s}\right)=0.005405
$$

The same calculation for the 2000 parameters yields

$$
\operatorname{Cov}\left(\Delta \hat{D}, \Delta \hat{C}^{s}\right)=0.00324
$$

Recall that the equity premium is proportional to the covariance: $E P=\gamma \operatorname{Cov}(\Delta \hat{D}, \Delta \hat{C})$. The increase in stockholders' share of aggregate labor income that took place between 1962 and 2000 implies a decrease of the covariance, and the ex ante equity premium, of $(0.005405-0.00324) / 0.005405=40 \%$.

However, the above exercise is overly restrictive since the absence of bond trading implies that the consumption process is exogenously determined. Below we develop a full-fledged asset pricing model. We then allow bond trading, but impose borrowing constraints. It turns out that the results, in terms of percentage change of covariance and therefore the equity premium, are basically unchanged. The main difference is that the level of $\operatorname{Cov}(\Delta \hat{D}, \Delta \hat{C})$ is lower, as the stockholder can smooth part of the variation in his income through the bond market.

\section{$2.3 \quad$ Full model setup}

There are two quasi-representative infinitively lived households: (i) One stockholder (denoted by superscript $s$ ) and, (ii) one non-stockholder (denoted by superscript $n$ ). Household $i$ 's preferences are represented by

$$
E \sum_{t=0}^{\infty} \beta^{t} u\left(C_{t}^{i}\right), \quad i=\{s, n\}
$$

\footnotetext{
${ }^{11}$ The negative correlation comes from the fact that the variance of $\frac{D_{t}}{Y_{t}^{a}}$ is higher than the variance of $\frac{Y_{t}^{a}}{Y_{t-1}^{a}}$, and that $W_{t}^{s}=\eta^{s}\left(1-\frac{D_{t}}{Y_{t}^{a}}\right) Y_{t}^{a}$.
} 
where $\beta$ is the subjective discount factor, $C_{t}^{i}$ agent $i^{\prime} s$ consumption and $u\left(C_{t}\right)=\frac{C_{t}^{1-\gamma}}{1-\gamma}$ is a constant relative risk-aversion utility function. We could define measures for each of the two agents. But these measures are irrelevant, only the agents' respective income shares matter, as long as preferences are CRRA.

There are two endowment trees, named labor and dividend, which give "fruit" every period. The stockholder owns the dividend tree and receives the dividend $D_{t}$ every period. The claims on the labor tree endowment are divided between the households in fixed fractions. Denote labor income of household $i$ by $W_{t}^{i}$.

Claims on future endowments are not tradable, but there is a market for 1-period discount bonds. Let $B_{t}^{i}$ denote bond holdings for household $i$ at the beginning of period $t$. There are only two prices in the model - the ex-dividend stock price $P_{t}$ and the bond price $Q_{t}=\frac{1}{1+r_{t}}$, where $r_{t}$ is interpreted as the risk-free interest rate between period $t$ and $t+1$.

The problems of the two households can be written recursively as:

$$
\begin{array}{rlrl}
V\left(B_{t}^{i} ; W_{t}^{i}, D_{t}\right)= & \max _{C_{t}^{i}, B_{t+1}^{i}} u\left(C_{t}^{i}\right)+\beta E_{t} V\left(B_{t+1}^{i} ; W_{t+1}^{i}, D_{t+1}\right) \\
& \text { s.t. } & \\
C_{t}^{s}+\frac{1}{1+r_{t}} B_{t+1}^{s}= & B_{t}^{s}+W_{t}^{s}+D_{t} & & \text { for the stockholder } \\
C_{t}^{n}+\frac{1}{1+r_{t}} B_{t+1}^{n}= & B_{t}^{s}+W_{t}^{n} & & \text { for the non-stockholder } \\
B_{t+1}^{i} \geqslant & -\underline{B}^{i} & & i=\{s, n\}
\end{array}
$$

where the inequality is due to a borrowing constraint implying that $\underline{\mathrm{B}}^{i}$ is the exogenous maximum amount that household $i$ can borrow.

Denote the total endowment income of an agent by $Y_{t}^{i}$. Note that stockholder income is $Y_{t}^{s}=W_{t}^{s}+D_{t}$ while non-stockholder income is $Y_{t}^{n}=W_{t}^{n}$. GDP is the sum of labor and dividend income, $Y_{t}^{a} \equiv W_{t}^{s}+W_{t}^{n}+D_{t}$.

Bonds are in zero net supply. Market clearing in the bond market therefore requires:

$$
B_{t+1}^{s}+B_{t+1}^{n}=0
$$

\subsubsection{Optimality conditions}

By taking the first order condition with respect to bond holding we get the standard Euler equation (identical for both agents), adjusted for the occasionally binding borrowing constraint:

$$
\begin{aligned}
& 1=\left(1+r_{t}\right) \beta E_{t}\left\{\frac{u^{\prime}\left(C_{t+1}^{i}\right)}{u^{\prime}\left(C_{t}^{i}\right)}\right\} \forall i \text { s.th. } B_{t+1}^{i}>-\underline{B}^{i} \\
& 1>\left(1+r_{t}\right) \beta E_{t}\left\{\frac{u^{\prime}\left(C_{t+1}^{i}\right)}{u^{\prime}\left(C_{t}^{i}\right)}\right\} \forall i \text { s.th. } B_{t+1}^{i}=-\underline{B}^{i}
\end{aligned}
$$

The fact that bonds are priced by the non-constrained agent makes the risk-free interest rate $r$ lower and less volatile than in an economy without borrowing constraints. From (9) 
we see that the high values of $r_{t}$ that would have prevailed in absence of the borrowing constraint, because of agent $i^{\prime} s$ low intertemporal marginal rate of substitution $\beta E_{t}\left\{\frac{u^{\prime}\left(C_{t+1}^{i}\right)}{u^{\prime}\left(C_{t}^{i}\right)}\right\}$, where not priced into the bond price in the states where agent $i$ was constrained.

Analogously, by defining stock returns using $R_{t+1}^{e} \equiv \frac{P_{t+1}+D_{t+1}}{P_{t}}$ we can write the Euler equation for stock holdings:

$$
1=\beta E_{t}\left\{R_{t+1}^{e} \frac{u^{\prime}\left(C_{t+1}^{s}\right)}{u^{\prime}\left(C_{t}^{s}\right)}\right\} \text { for the stockholder }
$$

Stocks are priced only by stockholders. On top of the standard equity premium, which is generated by the covariance of consumption growth and stock returns, there is also a "liquidity premium" generated by the borrowing constraint on bonds, as in Guo (2004). We calibrate the model so that the liquidity premium plays a very limited role.

The following expression illustrates this relationship approximately in the case of a joint lognormal distribution of consumption growth and stock returns (all variables in $\operatorname{logs})^{12}$ :

$$
\text { Equity premium }=E\left[\hat{r}_{t}^{s}-\min _{i=s, n}\left\{\hat{r}_{t}^{s}, \hat{r}_{t}^{n}\right\}\right]+\gamma \operatorname{Cov}\left(\hat{g}_{t+1}, \hat{R}_{t+1}^{e}\right)-\frac{\operatorname{Var}\left(\hat{R}_{t+1}^{e}\right)}{2}
$$

where $g_{t+1} \equiv\left(\frac{C_{t+1}^{s}}{C_{t}^{s}}\right)$ and $r_{t}^{i}$ denotes the risk-free rate that would have prevailed if agent $i$ alone set $r_{t}$. The term in square brackets is the liquidity premium (the difference between the risk-free rate set by the stockholder and by the unconstrained agent), the covariance term is standard and the last term is a Jensen's inequality term for log approximations.

The liquidity premium will be strictly positive in periods where the stockholder is borrowing constrained, so that he would be willing to pay a higher interest rate $\hat{r}_{t}^{s}$ than the prevailing interest rate $\min \left\{\hat{r}_{t}^{s}, \hat{r}_{t}^{n}\right\}$.

\subsection{State variables and income processes}

Let $\lambda_{t} \equiv Y_{t}^{a} / Y_{t-1}^{a}$ denote GDP growth and $d_{t} \equiv \frac{D_{t}}{Y_{t}^{a}}$ the dividend fraction of GDP. Denote agent $i$ 's share of the aggregate labor income by $\eta^{i}$. The duplet $\left\{\lambda_{t}, d_{t}\right\}$ then defines the exogenous state. The income processes are defined in terms of the state by:

$$
\begin{aligned}
W_{t}^{i} & =\eta^{i}\left(1-d_{t}\right) Y_{t}^{a} \quad \text { for } i=s, n \\
D_{t} & =d_{t} Y_{t}^{a}
\end{aligned}
$$

The only endogenous state variable is $b_{t}^{s}$.

\subsection{Equilibrium definition}

Given the exogenous labor income and dividend income process of each agent, an equilibrium is defined by:

1. A pricing function for bonds for each of the agents, $Q^{s}\left(\lambda_{t}, d_{t}, b_{t}^{s}\right)$ and $Q^{n}\left(\lambda_{t}, d_{t}, b_{t}^{s}\right)$.

\footnotetext{
${ }^{12}$ And the risk-free rate is the $\log$ of the gross rate, $\hat{r}_{t}=\ln \left(1+r_{t}\right)$
} 
2. A function for choosing end-of-period bond holdings for the stockholder, $b_{t+1}^{s}\left(\lambda_{t}, d_{t}, b_{t}^{s}\right)$. This function implicitly determines the non-stockholder's bond holding and consumption for each of the agents.

3. A pricing function for stocks, $P\left(\lambda_{t}, d_{t}, b_{t}^{s}\right)$.

such that

- The Euler equations for bonds (8) and (9) hold

- The Euler equation for equity (10) holds

- The budget constraints (5) and (6) are satisfied

- There is a unique price $Q$ for the bond in the sense that the agents agree on the price of the bond, or if one of them is constrained the unconstrained agent prices the bond:

$$
\begin{aligned}
& Q=Q^{s}\left(\lambda_{t}, d_{t}, b_{t}^{s}\right)=Q^{n}\left(\lambda_{t}, d_{t}, b_{t}^{s}\right) \\
& Q=Q^{n}\left(\lambda_{t}, d_{t}, b_{t}^{s}\right) \geq Q^{s}\left(\lambda_{t}, d_{t}, b_{t}^{s}\right) \text { if } B_{t+1}^{s}=\underline{\mathrm{B}}^{s} \\
& Q=Q^{s}\left(\lambda_{t}, d_{t}, b_{t}^{s}\right) \geq Q^{n}\left(\lambda_{t}, d_{t}, b_{t}^{s}\right) \text { if } B_{t+1}^{n}=\underline{\mathrm{B}}^{n}
\end{aligned}
$$

- The bond market clearing condition (7) holds.

Note that the goods market clears by construction.

\subsection{Solution method}

To solve the model we rewrite it such that all variables are stationary. We do this by normalizing the appropriate variables by current GDP. Denoting the normalized variables by lower case letters this yields the following budget constraints, as stationarized versions of (5) and (6):

$$
\begin{aligned}
c_{t}^{s}+\frac{1}{1+r_{t}} b_{t+1}^{s} & =d_{t}+b_{t}^{s} / \lambda_{t}+w_{t}^{s} \\
c_{t}^{n}+\frac{1}{1+r_{t}} b_{t+1}^{n} & =b_{t}^{n} / \lambda_{t}+w_{t}^{n}
\end{aligned}
$$

Because of the non-linearities introduced by the occasionally binding borrowing constraints we need to solve the model numerically. We extend the numerical solution algorithm of Telmer (1993) to the present model. ${ }^{13}$ The algorithm involves discretizing the state-space and calculating the policy rules at each grid point. The equilibrium is found using a two step approach. We first solve for consumption and bond holdings for each of the two agents. In the second step, the equity pricing, consumption can be viewed as exogenous. Stock prices are then calculated such that the Euler equation (10) holds. We do this by imposing a timeinvariant function $P D\left(\lambda_{t}, d_{t}, b_{t}^{s}\right)$ for the price-dividend ratio. The value of this function at

\footnotetext{
${ }^{13}$ Thanks to Chris Telmer for making his Fortran code publicly available.
} 
all gridpoints is found by iteration using the fixed point property. We use a fine grid for the endogenous bond holding variable and discretize it on 1020 points.

The above approach requires discretization of the exogenous income processes. We use the Tauchen and Hussey (1991) algorithm for this purpose. A grid of 3 values for $\lambda$ and 6 for $d$ approximates the VAR that describes the income processes well. We re-scale the states for GDP growth, $\Delta \hat{Y}^{a}$, to get zero trend growth. To calculate the moments implied by the model we run a 100000 periods simulation.

\section{Parameterization}

\subsection{Income processes}

The exogenous income processes are estimated from the data. Just like Heaton and Lucas (1996) we use a $\operatorname{VAR}(1)$ on $\left(\lambda_{t}, d_{t}\right)$ to describe the exogenous processes. Contrary to Heaton and Lucas (1996) we use a model economy without trend growth or idiosyncratic earnings risk. Because of the latter, individual labor income moments are equal to aggregate moments. The reason that we work without trend growth is that we use a standard constant relative risk-aversion setup with high risk-aversion. This setup implies a very low intertemporal elasticity of substitution and would generate a counterfactually high risk-free interest rate if combined with trend growth.

We assume that the process for GDP growth and the dividend share of GDP is unchanged over the entire post-war time period. In other words, we do not take into account any reduction in macro volatility that might have occurred in the last 20 years. Our exercise is in this sense orthogonal to exploring asset pricing implications of "the great moderation". We think it is beneficial to keep the quantitative effect of the mechanism emphasized in this paper separate from any such effects.

In our simulation we follow Heaton and Lucas (1996) and others in that we "gross up" the dividend series, $d_{t}$, from an average of $5.22 \%$ to $30 \%$ (15\% in their case) to better approximate the capital share of income.

From the SCF we get the stockholders' share of aggregate labor income, $\eta^{s}$. For 1962 we have $\eta^{s}=0.289$ and for $2000 \eta^{s}=0.505$. These values are not estimates, but populationweighted fractions from the survey.

\subsubsection{Data sources and definitions}

For GDP $\left(Y^{a}\right)$ we use the sum of CRSP dividends and Bureau of Economic Analysis aftertax labor income, both converted to real per capita values using the total expenditure deflator. This data is annual for 1949-2001.

The details of the SCF data are as follows. We use the triennial survey from 19832004. Labor income in the survey refers to labor income in the previous calendar year. We let "labor income" also include any unemployment compensation. We complement the SCF by its predecessor, the Survey of Financial Characteristics of Consumers (SFCC), to get the 1962 labor income of stockholders and non-stockholders. All aggregate SCF based 
values are generated using the SCF population weights. The SCF contains information that allows us to classify each household as stockholder or non-stockholder. We do this using an inclusive definition of stockholding (following Poterba and Samwick (1995)), including indirect holdings of stocks in mutual funds, but not pension savings that are locked in a retirement account, e.g. a $401 \mathrm{k} .{ }^{14}$

\subsubsection{Estimates}

The relevant moments of the estimated income processes, of the VAR, are reported in Table $1 .{ }^{15}$ Recall that we denote $\log$ values with "hats". $Y^{l}$ denotes aggregate labor income.

\begin{tabular}{llr}
\hline \hline & & Baseline estimate, \% \\
\hline Aggregate & $E\left(\Delta \hat{Y}^{a}\right)$ & 2.25 \\
& $\sigma\left(\Delta \hat{Y}^{a}\right)$ & 1.75 \\
& $\sigma(\Delta \hat{D})$ & 10.8 \\
& $\sigma\left(\Delta \hat{Y}^{l}\right)$ & 4.2 \\
& $\operatorname{Corr}\left(\Delta \hat{D}, \Delta \hat{Y}^{l}\right)$ & -0.86 \\
\hline \hline
\end{tabular}

Table 1. Moments of estimated income processes.

Heaton and Lucas (1996) report a substantially different estimate for the standard deviation of dividend income growth, $\sigma(\Delta \hat{D})=5.36 \%$. The reason for the difference is that they use data on dividends from NIPA (including dividends from all firms), while we use CRSP (only including publicly traded companies).

\subsection{Calibration}

A time period in the model represents a year. We calibrate the three remaining parameters: the borrowing limit which we set as a fraction of GDP, $\underline{b} \equiv \frac{\mathrm{B}^{i}}{Y^{a}}$, the subjective discount factor $\beta$ and the coefficient of relative risk-aversion $\gamma$. We set $\underline{b}=0.15$ implying that the maximum an agent can borrow is $15 \%$ of annual GDP, or approximately $30 \%$ of his annual labor income (in the 1962 parameterization). This is a less tight constraint than the $\underline{b}=(0.00,0.05)$ range that Heaton and Lucas (1996) explore, and the baseline value of $\underline{b}=0.1$ used in Guo (2004). The reason for this higher calibrated value is that we want to study an economy where the equity premium is generated mainly by covariance, not by a "liquidity premium" resulting from binding borrowing constraints. ${ }^{16}$ Given $\underline{b}$, we set $\beta=0.93$ to roughly match the

\footnotetext{
${ }^{14}$ This is the most inclusive definition for which the SCF and the SFCC contains data as the 1962 SFCC does not contain information about defined contribution pension plan assets. Furthermore, 401(k) plans, IRA's and Keoghs had not been instituted at that point in time. If we had included the defined contribution pension plans the (measured) increase in stockmarket participation from 1962 would have even greater.

${ }^{15}$ The values relating to labor income, i.e. $\sigma\left(\Delta \hat{Y}^{l}\right)$ and $\operatorname{Corr}\left(\Delta \hat{D}, \Delta \hat{Y}^{l}\right)$, depend on the assumption of a dividend share of $30 \%$ (and accordingly a labor share of $70 \%$ ).

${ }^{16}$ There is one unfortunate aspect of the model that we do not think reflect real world changes. It is an additional reason to not set the borrowing constraints too tight. The problem occurs when we compare two steady states with different degrees of inequality. Unless we change the individual borrowing limits, $\underline{B}_{t+1}^{s}$ and $\mathrm{B}_{t+1}^{n}$, in different directions (which goes against the assumption of zero net supply of bonds) the ratio
} 
historical level of the risk-free rate in the 1962 parameterization. The coefficient of relative risk-aversion is calibrated to $\gamma=15$ to roughly match the historical equity premium in the 1962 parameterization.

\section{Results}

\subsection{Quantitative results}

The only parameter we change between our two economies is the stockholders' share of aggregate labor income $\eta^{s}$. As in the SCF data, we let $\eta^{s}$ increase from 0.289 to 0.505 . As we argued earlier, and showed in Section 2.2, an increase in $\eta^{s}$ reduces the covariance between growth of stockholder total income $\Delta \hat{Y}_{t+1}^{s}$ and dividend income $\Delta \hat{D}_{t+1}$. Because of the borrowing constraints, consumption varies with income (with a scale difference), so a reduction in the covariance of growth of consumption and dividends, $\operatorname{Cov}\left(\Delta \hat{C}_{t+1}^{s}, \Delta \hat{D}_{t+1}\right)$, follows. In the end, what matters for the equity premium is the covariance of stockholder consumption growth and stock returns $\operatorname{Cov}\left(\Delta \hat{C}_{t+1}^{s}, R_{t+1}^{e}\right)$. In addition to the above mechanisms, this covariance is affected by endogenous changes in the time series properties of stock returns $R_{t+1}^{e}$.

Table 2 presents the second moments for agents' income and consumption, with an emphasis on the stockholder. First, note that, because of the change in the composition of income, $\operatorname{Cov}\left(\Delta \hat{Y}_{t}^{s}, \Delta \hat{D}_{t}\right), \operatorname{Cov}\left(\Delta \hat{C}_{t}^{s}, \Delta \hat{D}_{t}\right)$ and $\operatorname{Cov}\left(\Delta \hat{C}^{s}, \Delta \hat{R}_{t+1}^{e}\right)$ decrease from 1962 to 2000. This is the key difference between the two steady states that affect asset returns, as the equity premium decreases accordingly. Second, note the decrease in stockholders' total income volatility, $\sigma\left(\Delta \hat{Y}^{s}\right)$. This is also caused by the increased labor share in stockholders composition of income and the fact that labor income is less volatile than dividend income. Third, for non-stockholders changes in second moments are minimal - they only have labor income and $\sigma\left(\Delta \hat{Y}^{n}\right)$ is therefore unchanged. Finally, note that both agents can smooth most of the idiosyncratic income risk they face. In the 2000 calibration stockholders' consumption growth volatility, $\sigma\left(\Delta \hat{C}^{s}\right)$, approaches the aggregate volatility $\sigma\left(\Delta \hat{Y}^{a}\right)$ which is $1.75 \%$, as reported in Table 1.

\footnotetext{
between each agent's income and his borrowing limit, $\underline{\mathrm{B}}_{t+1}^{i} / Y_{t}^{i}$, will change. This affects the agents' ability to smooth consumption and therefore affect both the risk-free rate and the stock returns. In particular, ceteris paribus, the relatively tightened borrowing limit for the stockholder (lower borrowing limit as a fraction of his income, $\left.\underline{\mathrm{B}}_{t+1}^{s} / Y_{t}^{s}\right)$ will increase the liquidity premium, and thereby the equity premium. The effect on the risk-free interest rate is ambiguous as the stockholder's tightened $\mathrm{B}_{t+1}^{s} / Y_{t}^{s}$ will push it down at the same time as the non-stockholder will push it up, because of his relatively relaxed borrowing limit $\left(\underline{\mathrm{B}}_{t+1}^{n} / Y_{t}^{n}\right.$ increases as $Y_{t}^{n}$ fall).

These effects are neglible with the looser borrowing constraint calibration that we use.
} 


\begin{tabular}{lllr}
\hline \hline & 1962 & 2000 & \% change \\
\hline $\operatorname{Cov}\left(\Delta \hat{Y}^{s}, \Delta \hat{D}\right)$ & 56.94 & 35.94 & -36.9 \\
$\operatorname{Cov}\left(\Delta \hat{C}^{s}, \Delta \hat{D}\right)$ & 17.69 & 14.28 & -19.3 \\
$\operatorname{Cov}\left(\Delta \hat{C}_{t}^{s}, \Delta \hat{R}_{t+1}^{e}\right)$ & 20.45 & 11.20 & -45.2 \\
$\sigma\left(\Delta \hat{Y}^{s}\right)$ & 0.054 & 0.035 & -34.4 \\
$\sigma\left(\Delta \hat{Y}^{n}\right)$ & 0.042 & 0.042 & 0.0 \\
$\sigma\left(\Delta \hat{C}^{s}\right)$ & 0.022 & 0.019 & -11.4 \\
$\sigma\left(\Delta \hat{C}^{n}\right)$ & 0.015 & 0.016 & 1.4 \\
\hline \hline
\end{tabular}

Table 2. Second moments for agents' income and consumption, in percent.

Table 3 contains the asset pricing results. First, note that the equity premium falls by $45 \%$, from $3.0 \%$ in the 1962 calibration to $1.7 \%$ in 2000 . The main reason is the above mentioned decrease in $\operatorname{Cov}\left(\Delta \hat{C}_{t}^{s}, \Delta \hat{D}_{t}\right)$. In Table 3 we also report how much of the equity premium comes from the fact that the stockholder is occasionally borrowing constrained (i.e. the liquidity premium) and how much of the equity premium is due to covariance.

Second, note that in addition to the decrease in the equity premium we observe a substantial increase in the risk-free rate. The return to stocks, $R^{e}$, therefore decrease only slightly. The increase in $R^{f}$ is caused by a decrease in the precautionary savings motive. The reason is that $\sigma\left(\Delta \hat{Y}^{s}\right)$ is lower in 2000, and as a result the stockholder is borrowing constrained less often. No counteracting mechanism applies to the non-stockholder. Accordingly, the risk-free rate in the 2000 parameterization increases towards the value obtained in a model without borrowing constraints. For the same reason, the decrease in $\sigma\left(\Delta \hat{Y}^{s}\right)$ reduces the liquidity premium. On the last line of Table 3 we report the fraction of periods in which one agent is constrained. It decreases from 0.21 in 1962 inequality to 0.16 in 2000. Finally, note that the level of the Sharpe ratio is below the historical value in annual data (approximately 0.50 for the S\&P 500), and that it is lower in the 2000 calibration than in the 1962 calibration.

\begin{tabular}{lrrr}
\hline \hline & 1962 & 2000 & \% change \\
\hline$E\left(R^{f}\right)$ & 1.81 & 2.93 & 61.8 \\
$E\left(R^{e}\right)$ & 4.84 & 4.60 & -5.1 \\
$E\left(R^{e}\right)-E\left(R^{f}\right)$ & 3.03 & 1.67 & -45.0 \\
$\frac{E\left(R^{e}\right)-E\left(R^{f}\right)}{\sigma\left(R^{e}\right)}$ & 0.24 & 0.20 & -17.7 \\
Liquidity premium & 0.43 & 0.18 & -58.0 \\
Covariance premium & 2.61 & 1.49 & -42.8 \\
Fraction of periods constrained & 0.21 & 0.16 & -23.8 \\
\hline \hline
\end{tabular}

Table 3. Asset returns, in percent. 


\subsection{Robustness}

The key result - that the equity premium falls substantially when stockholders' share of aggregate labor income increases - is not sensitive to any of the parameters. This is shown in Table 4, where the change in the equity premium with year 2000 inequality compared to 1962 inequality is documented for several values of the borrowing constraint $\underline{b}$ and the risk-aversion $\gamma$. We note that the size of the change in the equity premium is slightly decreasing in $\underline{b}$. The reason is that for a less tight borrowing constraint $\underline{b}$, agents can smooth idiosyncratic income variation better, so that composition of income for an individual agent, i.e. the stockholder, has less of an effect on his consumption volatility and thereby the equity premium. The change of the equity premium is not very sensitive to the value of $\gamma$. Interestingly the relationship is non-monotone. Finally, we note that a decrease in the capital (dividend) income share $d$, reduces the size of the change of the equity premium.

\begin{tabular}{l|lll}
\hline \hline & $\underline{\mathrm{b}}=0.10$ & $\underline{\mathrm{b}}=0.15$ & $\underline{\mathrm{b}}=0.20$ \\
\hline$\gamma=10$ & -50.2 & -46.4 & -41.0 \\
$\gamma=15$ & -51.0 & -45.0 & -45.0 \\
$\gamma=20$ & -49.9 & -45.6 & -38.2 \\
\hline \hline
\end{tabular}

Table 4. Percentage change in the equity premium with year 2000 inequality compared to 1962 inequality.

Below we document the sensitivity of the level of, as opposed to the change between 1962 and 2000, asset pricing results to the parameters of the model. $\beta$ sets the level of $R^{f}$ and thereby $R^{e}$. As seen in Table $5, R^{f}$ is decreasing in $\gamma$. Furthermore, an increase in $\underline{b}$ enhances the ability to smooth consumption and thereby increases the level of $R^{f}$. For the same reason the equity premium, and therefore $R^{e}$, is decreasing in $\underline{b}$, as shown in Table 6. As a side point this is an interesting result, as it reasonable to believe that borrowing constraints have loosened over time due to financial development and in this way contributed further to a falling ex ante equity premium as well as an increasing risk-free rate. In the same table we note that the equity premium, not surprisingly, is increasing in $\gamma$. The Sharpe ratio behaves similarly to the equity premium in these two dimensions. We also note that the capital income share $d$ has effects for asset returns - an increase in $d$ leads to a reduction in $R^{f}$ and an increase in the equity premium.

\begin{tabular}{r|rrr}
\hline \hline & $\underline{\mathrm{b}}=0.10$ & $\underline{\mathrm{b}}=0.15$ & $\underline{\mathrm{b}}=0.20$ \\
\hline$\gamma=10$ & 3.67 & 4.36 & 4.68 \\
$\gamma=15$ & 0.83 & 1.81 & 2.26 \\
$\gamma=20$ & -2.51 & -1.18 & -0.58 \\
\hline \hline
\end{tabular}

Table 5. $R^{f} 1962$ for various parameter values, in percent. 


\begin{tabular}{r|rrr}
\hline \hline & $\underline{\mathrm{b}}=0.10$ & $\underline{\mathrm{b}}=0.15$ & $\underline{\mathrm{b}}=0.20$ \\
\hline$\gamma=10$ & 2.85 & 1.91 & 1.50 \\
$\gamma=15$ & 4.44 & 3.03 & 2.41 \\
$\gamma=20$ & 6.15 & 4.14 & 3.25 \\
\hline \hline
\end{tabular}

Table 6. $R^{e}-R^{f} 1962$ for various parameter values, in percent.

\section{Summary}

In this paper we have documented a substantial increase in stockholders' share of aggregate labor income in the U.S. since 1962, due to both increased stockmarket participation and increased inequality in labor income. We presented a mechanism for how this increase has affected the ex ante equity premium (i.e. the equity discount rate). The mechanism works through the composition of income of stockholders. The increase in the fraction of stockholders' income that consists of labor income decreases the covariance between stockholder income growth and dividend growth. We show in an asset pricing model with limited stockmarket participation and labor income that this implies a substantial decrease of the ex ante equity premium, and that this result is robust with respect to the calibration. When we feed in the stockholder labor income share for 1962 and 2000 in our model the $e x$ ante equity premium decreases from 300 basis points to 170 basis points, which amounts to a $45 \%$ change. This number roughly coincides with the historically observed decrease of 160 basis points (39\% change) in the post-1951 equity premium implied by the simple dividend growth model in Fama and French (2002). 


\section{A Appendix}

\section{A.1 Tables}

\begin{tabular}{rrrrr}
\hline \hline Year & $E\left(W^{s}\right)$ & $E\left(W^{n}\right)$ & $P(\%)$ & $\eta^{s}(\%)$ \\
\hline 1962 & 38,408 & 22,221 & 19.0 & 28.9 \\
1982 & 53,116 & 26,022 & 19.7 & 33.4 \\
1988 & 68,915 & 31,438 & 19.7 & 35.0 \\
1991 & 59,780 & 30,460 & 21.2 & 34.5 \\
1994 & 64,284 & 30,745 & 22.5 & 37.8 \\
1997 & 66,621 & 30,473 & 27.3 & 45.1 \\
2000 & 79,328 & 33,137 & 29.9 & 50.5 \\
2003 & 75,427 & 33,563 & 27.5 & 46.1 \\
\hline \hline
\end{tabular}

Table A1. $E\left(W^{i}\right)$ denotes average labor income per household (by group) in year 2000 dollars, $P$ the stockmarket participation rate and $\eta^{s}$ stockholders' share of aggregate labor income.

\section{A.2 The equity pricing algorithm}

The equity pricing algorithm relies on earlier work by Mehra and Prescott (1985). The aim is to find stock returns such that Euler equation for equity (10) holds. All variables specific to an agent refer to the stockholder, so formally they should have superscript $s$, but this will be dropped here to simplify notation. Start with the standard asset pricing formula

$$
P_{t}=E_{t}\left\{M_{t+1}\left(P_{t+1}+D_{t+1}\right)\right\}
$$

where $M_{t+1}=\beta\left(\frac{C_{t+1}}{C_{t}}\right)^{-\gamma}$. We can rewrite this as

$$
\begin{aligned}
\frac{P_{t}}{D_{t}} & =E_{t}\left\{M_{t+1}\left(\frac{P_{t+1}}{D_{t+1}} \frac{D_{t+1}}{D_{t}}+\frac{D_{t+1}}{D_{t}}\right)\right\} \\
\frac{P_{t}}{D_{t}} & =E_{t}\left\{M_{t+1}\left(\frac{P_{t+1}}{D_{t+1}}+1\right) \frac{D_{t+1}}{D_{t}}\right\}
\end{aligned}
$$

Impose a stationary function $\frac{P}{D}()$ of the state variables $\lambda_{t}, d_{t}$ and $b_{t}^{s}$. Then

$$
\frac{P}{D}\left(\lambda_{t}, d_{t}, b_{t}^{s}\right)=E_{t}\left\{M_{t+1}\left(\frac{P}{D}\left(\lambda_{t+1}, d_{t+1}, b_{t+1}^{s}\right)+1\right) \frac{D_{t+1}}{D_{t}}\right\}
$$

Given the discretized nature of our 3 state variables the RHS can be written as a sum over a grid in 3 dimensions. In practice we limited the two exogenous state variables to only one dimension with 18 states, so the RHS reduces to a sum over these 18 exogenous states. Denote the time $t$ state by $k . \Pi_{k i}$ is then the transition probability of moving from state $k$ to state $i$, where state $i$ occurs at time $t+1 . b_{t+1}$ is chosen at time $t$ and is a function of the time $t$ state variables. We can rewrite $\frac{D_{t+1}}{D_{t}}$ in terms of the current dividend and the 
next period state variables:

$$
\frac{D_{t+1}}{D_{t}}=\frac{d_{i}}{d_{t}} \lambda_{i}
$$

Our expression then simplifies to:

$$
\frac{P}{D}\left(\lambda_{t}, d_{t}, b_{t}^{s}\right)=\sum_{i=1}^{18} \Pi_{k i}\left\{\begin{array}{c}
\beta\left(\frac{C_{t+1}\left(\lambda_{i}, d_{i}, b_{t+1}^{s}\left(\lambda_{t}, d_{t}, b_{t}^{s}\right)\right)}{C_{t}}\right)^{-\gamma} * \\
\left(\frac{P}{D}\left(\lambda_{i}, d_{i}, b_{t+1}^{s}\left(\lambda_{t}, d_{t}, b_{t}^{s}\right)\right)+1\right) \frac{d_{i}}{d_{t}} \lambda_{i}
\end{array}\right\}
$$

The function $\frac{P}{D}()$ must satisfy this equality at all the gridpoints in the state space.

We solve for the $\frac{P}{D}$ () function numerically using an initial arbitrary guess and then iterating locally and globally until the function converges. 


\section{References}

[1] Abel, A. (2006), "Equity premia with benchmark levels of consumption: closed-form results", NBER working paper 12290.

[2] Basak, S. and D. Cuoco (1998), "An equilibrium model with restricted stock market participation", Review of Financial Studies, Vol 11, pp. 309-341.

[3] Bowlus, A. and J.-M. Robin (2004), "Twenty years of rising inequality in US lifetime labor income values", Review of Economic Studies, Vol. 71, pp. 709-742.

[4] Calvet, L., M. Gonzalez-Eiras and P. Sodini (2004), "Financial innovation, market participation and asset prices", Journal of Financial and Quantitative Analysis, Vol 39, pp. 431-459.

[5] Campbell, J. (2007), "Estimating the equity premium", NBER working paper 13423.

[6] Constantinides, G. , J. Donaldson and R. Mehra (2002), "Junior can't borrow: A new perspective on the equity premium puzzle", Quarterly Journal of Economics, Vol 117, pp. 269-296.

[7] Dew-Becker, I. and R. Gordon (2005), "Where did the productivity growth go? Inflation dynamics and the distribution of income", NBER working paper 11842.

[8] Fama, E. and K. French, (2002), "The equity premium", Journal of Finance, Vol LVII. No. 2, pp. 637-659.

[9] Favilukis, J. (2007), "Inequality, stock market participation, and the equity premium", manuscript, New York University.

[10] Freeman, M. (2006), "An explanation of the declining ex-ante equity risk premium", University of Exeter working paper 06/03.

[11] Gollier, C. (2001), "Wealth inequality and asset pricing", Review of Economic Studies, Vol. 68, pp. 181-203.

[12] Gomes, F. and A. Michaelides (2006), "Asset pricing with limited risk sharing and heterogeneous agents", forthcoming Review of Financial Studies.

[13] Guo, H. (2004), "Limited stock market participation and asset prices in a dynamic economy", Journal of Financial and Quantitative Analysis, Vol. 39, No. 3, pp. 495-516.

[14] Guvenen, F. (2005), "A parsimonious macroeconomic model for asset pricing: Habit formation or cross-sectional heterogeneity?", manuscript, University of Texas at Austin.

[15] Hatchondo, J. (2005), "A quantitative study of the role of wealth inequality on asset prices", Federal Reserve Bank of Richmond, working paper 05-12. 
[16] Heathcote, J., K. Storesletten and G. Violante (2004), "The cross-sectional implications of rising wage inequality in the United States", CEPR Discussion Paper No. 4296.

[17] Heaton, J. and D. Lucas (1996), "Evaluating the effects of incomplete markets on risk-sharing and asset pricing", Journal of Political Economy, 104, pp. 668-712.

[18] Heaton, J. and D. Lucas (1999), "Stock prices and fundamentals", NBER Macroeconomic Annual 1999, ed. Ben S. Bernanke and Julio Rotemberg, pp. 213-63.

[19] Iacoviello, M. (2007), "Household debt and income inequality, 1963-2003", Journal of Money, Credit and Banking, forthcoming.

[20] Jagannathan, R., E. McGrattan and A. Scherbina (2000), "The declining U.S. equity premium", Quarterly Review, Federal Reserve Bank on Minneapolis, Fall, pp. 3-19.

[21] Katz, L. and D. Autor (1999), "Changes in the wage structure and earnings inequality", in Handbook of Labor Economics, O. Ashenfelter \& D. Card (ed.), chapter 26, pages 1463-1555.

[22] Kim, C., J. C. Morley and C. Nelson (2004), "Is there a positive relationship between stock market volatility and the equity premium", Journal of Money, Credit and Banking, Vol 36, pp. 339-360.

[23] Kim, C., J. C. Morley and C. Nelson (2005), "The structural break in the equity premium.", Journal of Business \& Economics Statistics, Vol 23, pp. 181-191.

[24] Krueger, D. and F. Perri (2006), "Does income inequality lead to consumption inequality? Evidence and theory", Review of Economic Studies, Vol.73(1), pp. 163-193.

[25] Lettau, M., S. Ludvigson and J. Wachter (2007), "The declining equity premium: What role does macroeconomic risk play", The Review of Financial Studies, forthcoming.

[26] Lustig, H. and S. Van Nieuwerburgh (2006), "Can housing collateral explain long-run swings in asset returns?", NBER working paper 12766.

[27] Mankiw, G. and S. Zeldes (1991), "The consumption of stockholders and nonstockholders", Journal of Financial Economics, 29, pp. 113-135.

[28] Mehra, R. and E. Prescott (1985), "The equity premium: A puzzle." Journal of Monetary Economics, vol. 15, pp. 145-161.

[29] Nakajima, M. (2005), "Rising earnings instability, portfolio choice, and housing prices", mimeo.

[30] Pástor, L. and R. F. Stambaugh (2001), "The equity premium and structural breaks", Journal of Finance Vol 56, pp. 1207-1239.

[31] Piketty, T. and E. Saez (2003), "Income inequality in the United States, 1913-1998", The Quarterly Journal of Economics, 118(1), pp. 1-39. 
[32] Polkovnichenko, V. (2004), "Limited stock market participation and the equity premium", Finance Research Letters, Vol 1(1), pp. 24-34.

[33] Poterba, J. and A. Samwick (1995), "Stock ownership patterns, stock market fluctuations, and consumption", Brookings Papers on Economic Activity, Vol. 0(2), pp. 295-372.

[34] Primiceri, G. and T. van Rens (2004), "Inequality over the business cycle: Estimating income risk using micro-data on consumption", working paper.

[35] Santos, T. and P. Veronesi (2006), "Labor income and predictable stock returns", Review of Financial Studies, Vol 19(1), pp. 1-44.

[36] Storesletten, K., C. Telmer and A. Yaron (2004), "Cyclical dynamics in idiosyncratic labor-market risk", Journal of Political Economy, 2004, vol. 112 (3), pp. 695-717.

[37] Tauchen, G. and R. Hussey (1991), "Quadrature-based methods for obtaining approximate solutions to nonlinear asset pricing models", Econometrica, Vol 59(2), pp. 371-396.

[38] Telmer, C. (1993), "Asset-pricing puzzles and incomplete markets", Journal of Finance, 48, pp. $1803-32$.

[39] Vissing-Jørgensen, A. (2002), "Towards an explanation of household portfolio choice heterogeneity: Nonfinancial income and participation cost structures", NBER working paper 8884 . 


\section{Earlier Working Papers:}

For a complete list of Working Papers published by Sveriges Riksbank, see www.riksbank.se

Evaluating Implied RNDs by some New Confidence Interval Estimation Techniques

by Magnus Andersson and Magnus Lomakka....

Taylor Rules and the Predictability of Interest Rates

by Paul Söderlind, Ulf Söderström and Anders Vredin ......................................................... 2003:147

Inflation, Markups and Monetary Policy

by Magnus Jonsson and Stefan Palmqvist.....

Financial Cycles and Bankruptcies in the Nordic Countries by Jan Hansen........................................ 2003:149

Bayes Estimators of the Cointegration Space by Mattias Villani .................................................. 2003:150

Business Survey Data: Do They Help in Forecasting the Macro Economy?

by Jesper Hansson, Per Jansson and Mårten Löf

The Equilibrium Rate of Unemployment and the Real Exchange Rate:

An Unobserved Components System Approach by Hans Lindblad and Peter Sellin ........................ 2003:152

Monetary Policy Shocks and Business Cycle Fluctuations in a

Small Open Economy: Sweden 1986-2002 by Jesper Lindé

Bank Lending Policy, Credit Scoring and the Survival of Loans by Kasper Roszbach .......................... 2003:154

Internal Ratings Systems, Implied Credit Risk and the Consistency of Banks' Risk

Classification Policies by Tor Jacobson, Jesper Lindé and Kasper Roszbach .................................. 2003:155

Monetary Policy Analysis in a Small Open Economy using Bayesian Cointegrated

Structural VARs by Mattias Villani and Anders Warne

Indicator Accuracy and Monetary Policy: Is Ignorance Bliss? by Kristoffer P. Nimark ........................ 2003:157

Intersectoral Wage Linkages in Sweden by Kent Friberg .......................................................... 2003:158

Do Higher Wages Cause Inflation? by Magnus Jonsson and Stefan Palmqvist ............................. 2004:159

Why Are Long Rates Sensitive to Monetary Policy by Tore Ellingsen and Ulf Söderström .................. 2004:160

The Effects of Permanent Technology Shocks on Labor Productivity

and Hours in the RBC model by Jesper Lindé........................................................................ 2004:161

Credit Risk versus Capital Requirements under Basel II: Are SME Loans and Retail

Credit Really Different? by Tor Jacobson, Jesper Lindé and Kasper Roszbach

Exchange Rate Puzzles: A Tale of Switching Attractors

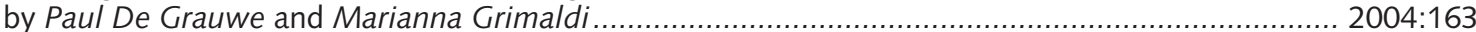

Bubbles and Crashes in a Behavioural Finance Model

by Paul De Grauwe and Marianna Grimaldi.

Multiple-Bank Lending: Diversification and Free-Riding in Monitoring

by Elena Carletti, Vittoria Cerasi and Sonja Daltung.............................................................. 2004:165

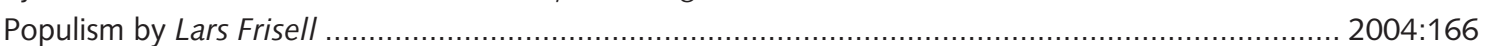

Monetary Policy in an Estimated Open-Economy Model with Imperfect Pass-Through

by Jesper Lindé, Marianne Nessén and Ulf Söderström

Is Firm Interdependence within Industries Important for Portfolio Credit Risk?

by Kenneth Carling, Lars Rönnegård and Kasper Roszbach

$2004: 168$

How Useful are Simple Rules for Monetary Policy? The Swedish Experience

by Claes Berg, Per Jansson and Anders Vredin

The Welfare Cost of Imperfect Competition and Distortionary Taxation

by Magnus Jonsson

A Bayesian Approach to Modelling Graphical Vector Autoregressions

by Jukka Corander and Mattias Villani

Do Prices Reflect Costs? A study of the price- and cost structure of retail payment

services in the Swedish banking sector 2002 by Gabriela Guibourg and Biörn Segendorf

Excess Sensitivity and Volatility of Long Interest Rates: The Role of Limited

Information in Bond Markets by Meredith Beechey.

State Dependent Pricing and Exchange Rate Pass-Through

by Martin Flodén and Fredrik Wilander.

The Multivariate Split Normal Distribution and Asymmetric Principal

Components Analysis by Mattias Villani and Rolf Larsson

Firm-Specific Capital, Nominal Rigidities and the Business Cycle

by David Altig, Lawrence Christiano, Martin Eichenbaum and Jesper Lindé

Estimation of an Adaptive Stock Market Model with Heterogeneous Agents by Henrik Amilon ........ 2005:177

Some Further Evidence on Interest-Rate Smoothing: The Role of Measurement

Errors in the Output Gap by Mikael Apel and Per Jansson...... 
Swedish Intervention and the Krona Float, 1993-2002

by Owen F. Humpage and Javiera Ragnartz

A Simultaneous Model of the Swedish Krona, the US Dollar and the Euro

by Hans Lindblad and Peter Sellin....

Testing Theories of Job Creation: Does Supply Create Its Own Demand?

by Mikael Carlsson, Stefan Eriksson and Nils Gottfries

Down or Out: Assessing The Welfare Costs of Household Investment Mistakes

by Laurent E. Calvet, John Y. Campbell and Paolo Sodini

Efficient Bayesian Inference for Multiple Change-Point and Mixture Innovation Models

by Paolo Giordani and Robert Kohn ....

Derivation and Estimation of a New Keynesian Phillips Curve in a Small Open Economy

by Karolina Holmberg.

Technology Shocks and the Labour-Input Response: Evidence from Firm-Level Data

by Mikael Carlsson and Jon Smedsaas

Monetary Policy and Staggered Wage Bargaining when Prices are Sticky

by Mikael Carlsson and Andreas Westermark

The Swedish External Position and the Krona by Philip R. Lane

Price Setting Transactions and the Role of Denominating Currency in FX Markets

by Richard Friberg and Fredrik Wilander

The geography of asset holdings: Evidence from Sweden

by Nicolas Coeurdacier and Philippe Martin

Evaluating An Estimated New Keynesian Small Open Economy Model

by Malin Adolfson, Stefan Laséen, Jesper Lindé and Mattias Villani....

The Use of Cash and the Size of the Shadow Economy in Sweden

by Gabriela Guibourg and Björn Segendorf.....

Bank supervision Russian style: Evidence of conflicts between micro- and macro-

prudential concerns by Sophie Claeys and Koen Schoors

Optimal Monetary Policy under Downward Nominal Wage Rigidity

by Mikael Carlsson and Andreas Westermark ....

Financial Structure, Managerial Compensation and Monitoring

by Vittoria Cerasi and Sonja Daltung

Financial Frictions, Investment and Tobin's q by Guido Lorenzoni and Karl Walentin

Sticky Information vs. Sticky Prices: A Horse Race in a DSGE Framework

by Mathias Trabandt.

Acquisition versus greenfield: The impact of the mode of foreign bank entry

on information and bank lending rates by Sophie Claeys and Christa Hainz.....

Nonparametric Regression Density Estimation Using Smoothly Varying Normal Mixtures

by Mattias Villani, Robert Kohn and Paolo Giordani

The Costs of Paying - Private and Social Costs of Cash and Card

by Mats Bergman, Gabriella Guibourg and Björn Segendorf.

Using a New Open Economy Macroeconomics model to make real nominal

exchange rate forecasts by Peter Sellin....

Introducing Financial Frictions and Unemployment into a Small Open Economy Model

by Lawrence J. Christiano, Mathias Trabandt and Karl Walentin. 
Sveriges Riksbank

Visiting address: Brunkebergs torg 11

Mail address: se-103 37 Stockholm

Website: www.riksbank.se

Telephone: +46878700 00, Fax: +468210531

E-mail: registratorn@riksbank.se 